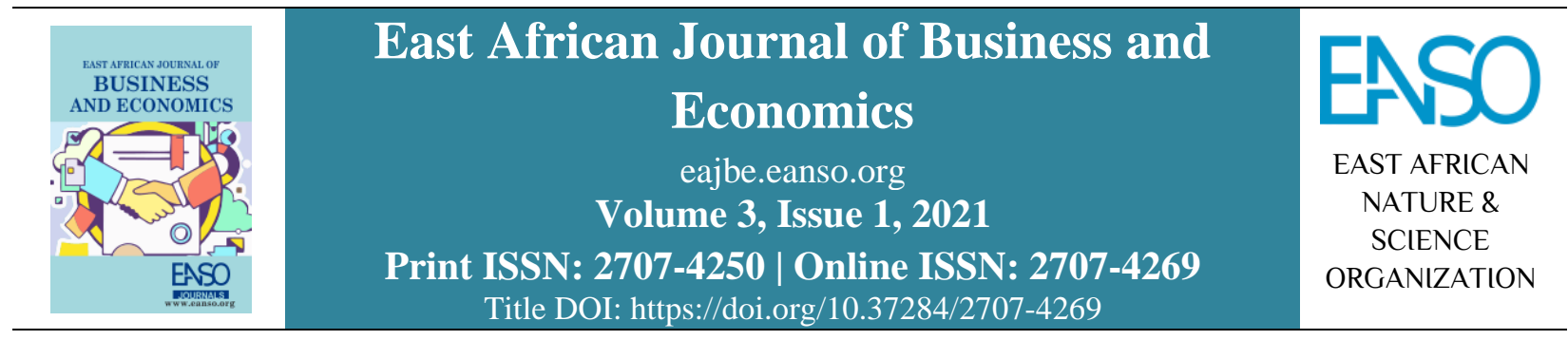

Original Article

\title{
The Relationship between Public Transport and the Location of Shanty Settlements in Kampala City
}

\author{
Ellen Byagabal \& Dr. Stephen Mukiibi $(P h D)^{1 *}$ \\ ${ }^{1}$ Department of Architecture and Physical Planning, Makerere University, P. O. Box 7062 Kampala, Uganda. \\ * ORCID: https://sandbox.orcid.org/0000-0002-4330-2135; Correspondence email: smukbs7@ gmail.com.
}

Article DOI: https://doi.org/10.37284/eajbe.3.1.365

\section{Date Published: ABSTRACT}

23 July 2021 This research was conducted to investigate the relationship between public transport and the occupation of shanty settlements in Kampala. It is hoped that

Keywords: results from the study will inform future policy formulation by the government and planning of transport infrastructure and low-income housing developments.

Public Transport, The study thus sought to examine whether a relationship exists between the cost

Paratransit, of available public transportation and the choice to reside in these shanty

Slums, settlements in Kampala. The study established that increased availability of low-

Slums, cost public transport allows city residents to seek out better quality and cheaper

Informal housing further from the city centre (their affordability index being maintained or

Settlements, reduced). Influential government policy decisions such as maximum caps on fares Affordability. and subsidisation of public transport vehicles can ensure increased supply and therefore lower the cost of public transport. Increased mobility can result in lower demand for cheap inner-city housing that may in turn stem the growth of illegal settlements, resulting in healthier city development for all.

\section{APA CITATION}

Byagaba, E., \& Mukiibi, S. (2021). The Relationship between Public Transport and the Location of Shanty Settlements in Kampala City. East African Journal of Business and Economics, 3(1), 130-146. https://doi.org/10.37284/eajbe.3.1.365

\section{CHICAGO CITATION}

Byagaba, Ellen, and Stephen Mukiibi. 2021. "The Relationship between Public Transport and the Location of Shanty Settlements in Kampala City". East African Journal of Business and Economics 3 (1), 130-146. https://doi.org/10.37284/eajbe.3.1.365.

\section{HARVARD CITATION}

Byagaba, E., and Mukiibi, S. (2021) "The Relationship between Public Transport and the Location of Shanty Settlements in Kampala City”, East African Journal of Business and Economics, 3(1), pp. 130-146. doi: 10.37284/eajbe.3.1.365.

\section{IEEE CITATION}

E., Byagaba, and S., Mukiibi, "The Relationship between Public Transport and the Location of Shanty Settlements in Kampala City”, EAJBE, vol. 3, no. 1, pp. 130-146, Jul. 2021.

130| This work is licensed under a Creative Commons Attribution 4.0 International License. 


\section{MLA CITATION}

Byagaba, Ellen, and Stephen Mukiibi. "The Relationship between Public Transport and the Location of Shanty Settlements in Kampala City". East African Journal of Business and Economics, Vol. 3, no. 1, Jul. 2021, pp. 130-146, doi:10.37284/eajbe.3.1.365

\section{INTRODUCTION}

Transportation planning decisions affect land use, both directly by determining which land is devoted to transport facilities such as roads, parking lots, and ports, and indirectly by affecting the relative accessibility and development costs in different locations (Kelly, 1994; Boarnet et al., 2008; OTREC, 2009). The transport network determines which areas are accessible and therefore where housing can develop. The cost of transport determines who can afford to access particular neighbourhoods. The transport network also relies on the location of housing. The relationship between the two is mutually beneficial. Neighbourhoods readily accessible by public transport allow for mixed-income housing. Those only accessible by private car are typically for high-income earners. Housing outside the city is usually much more affordable than that found in the inner-city but may in fact be more expensive when balanced against costs incurred in commuting into the city centre (Duc, 2007).

Litman (2011) argues that choice of housing location impacts lifestyle greatly and therefore is a carefully considered issue. A home is defined as easily accessible if one can conveniently and affordably access work and other amenities. The applied linkages between public transport planning and poverty reduction (most clearly defined by housing) in much of the world, however, are weak. City planners, without this knowledge, miss an opportunity to contribute toward government poverty reduction objectives and could even worsen socio-economic and spatial inequality in the city (Hagans, 2013). Research has shown that the single most influencing factor is accessibility (Lipman, 2006). Aside from accessibility, the following factors influence consumer housing location preferences (Litman, 2011).

\section{Slums Development}

According to United Nations Statistics Division, in 2014, 880 million people or around a quarter of the world's urban population resided in slums (United Nations, 2021). In sub-Saharan Africa alone, 62\% of the region's urban population lives in slums (Vinay et al, 2017). In the last decade, the urban population in Africa has increased by $36 \%$. This is alarming considering that economic growth and development in southern countries have not matched this exponential population growth. Cities are growing faster than the administration's capacity to provide for their residents.

The location of affordable low-income housing should be a major concern of urban policy today and should be explicitly considered in a wide variety of contexts from resettlement location choices to largescale planning and transport strategies for urban areas. The pervading impression is that governments of most African countries are failing to make an appreciable impact on the endemic poverty and social degradation in the urban areas; perhaps because, rather than innovate new solutions for their context, they continue to laud the ideals of those who governed before them (Mabogunje, 2006).

\section{Smart Growth vs Urban Sprawl}

Smart growth (also called new urbanism, particularly when applied at the site or neighbourhood level) consists of land use development patterns that emphasise accessibility and modal diversity, as opposed to dispersed, automobile-dependent development, often called sprawl (Litman, 2014). Smart growth desires the development of mixed-use, self-sufficient developments inter-connected by inexpensive mass 
transportation. This movement generally seeks to encourage settlement in dense communities at the city centres rather than in large suburbs at the outskirts of the city. Smart growth can happen organically if city centres are well planned to provide for non-motorised transport and can provide affordable housing for all income levels. The city must encourage the development of legal highdensity housing in its centre, which targets high, middle and low-income alike. Unfortunately, highvalue inner-city land cannot be afforded by the urban poor and is never developed with low-income housing in mind. However, the principles of smart growth can then be bolstered by those of urban sprawl. Transport structures engineered to enable city workers to move easily around the city and commute home in the suburbs by cheap mass transit become possible.

Sprawl, as a concept of town development, has some advantages. Holcombe (1999) argues that in fact, sprawl can be healthy and efficient if well regulated. Sprawl can develop in the following forms: leapfrog developments that are at the outskirts of the city and encourage commercial development between them and the city, strip or ribbon developments that develop along major highways (close to transit lines) and low-density single dimension developments that are formed far from the city purely as affordable residential areas. Holcombe's studies show that people generally prefer to live in larger, more comfortable and cheaper housing outside the city and commute to work. The primary problem with sprawl is when developed for private transport, it causes traffic congestion and environmental pollution.

\section{Public Transport}

Public transport is the primary means of access to work and amenities and should be affordable to the majority of the population it serves. The purpose of 'transportation' and 'mobility' is to gain access to destinations, activities, services and goods. Thus, access is the ultimate objective of all transportation.
If public transport is attractive and comfortable to use, even those who can afford private transport will opt to use it. Areas with good access to public transit and well-designed urban spaces that are walkable and bike-able become highly attractive places for people to live, work, learn, play, and interact. Such an environment enhances a city's economic competitiveness, reduces local pollution and global greenhouse gas emissions, and promotes inclusive development (Suzuki et al., 2013). Public transport is sustainable (economically, socially and environmentally) if the purposes for which commuters require transport are understood and met, as well as considerations of their financial ability, understood and addressed. The provision of an apt public transport system can greatly liberate their choice of where to locate their homes, no matter the income bracket they fall into (Starkey and Hine, 2014).

\section{Government's Role}

Public transport is an expensive venture to undertake. Where governments do little, paratransit systems develop to provide public transport. Paratransit systems are not regulated efficiently and operate as profit-driven businesses. They transfer all burden of cost to the commuter. Where the government cannot directly provide mass transit, it can develop a framework that would encourage its natural development and discourage the private vehicle, as well as provide controls on the paratransit system.

Increased investments in all types of public transport promise to help boost the urban economy of developing countries. The case of Japan is illustrative in this respect. In the post-WWII period, the Japanese government played a key role in urban transport by adopting public policies that discouraged automobile use and channelled investment in public transport. This urban transportation system contributed to rapid economic growth by minimising aggregate transportation costs, constraining the consumption of private 
automobiles, and encouraging savings (Pojani and Domic, 2015).

When new infrastructure reinforces car dependence, it encourages land use segregation, dispersal, and a hostile environment for pedestrians, cyclists and bus users. This leaves those without the option or desire to purchase cars with little choice on where they can reside. They must reside as close to what they need as is possible. This has bred 'ghettos' in world-class cities and slums in southern cities. While financial and administrative constraints perhaps bar the government from directly implementing a mass transport system, there is an opportunity for revision of policy framework and road infrastructure in order to support private investment in this area. Government subsidies can assist in lowering costs so that rates can be brought down to within affordable levels for the general populace (Holcombe, 1999).

\section{Sustainability in Transport}

Mass transit is more sustainable than private forms of transport. Mass transit hosts a large group of people at one time ensuring maximised use of energy in their transport. It is cheaper to transport 70 people in one bus than it is to transport the same number in 18 or more private vehicles. Mass transit is designed to be accessible by all and can safely handle special needs groups such as children and the disabled. Mass transit encourages the populace to walk or cycle short distances between terminals which results in a healthier population. The propensity to walk or cycle is affected by local planning and design that affects feelings of safety and convenience of access. In European cities, this can be seen quite clearly, although they are fair of the same economic standing. In the typical British city walking and cycling accounts for $35 \%$ of trips, while in Dutch cities, it is 60 to $65 \%$ (Greed \& Roberts, 1998). Dutch cities encourage walking and cycling by ensuring that all roads have clear and dedicated walkways and cycle lanes, bicycle stands outside businesses to lock up bicycles and so on.
Planning protects and promotes eco-friendly mass transport.

Residential settlements that provide real transport options influence economic activity, and they do not place a growing burden on their residents. A good public transport system reduces levels of pollution, improves access quality, especially for special needs groups, provides increased modal choice and creates an attractive and safe environment for all. It influences lifestyle choices and therefore housing development (UNCHS, 2001).

With a view to realising means of transport that integrate current economic, social and environmental objectives with minimal compromise on the ability of future generations to meet their needs, certain strategies can be undertaken. The concept of Avoid-Shift-Improve (ASI) is widely accepted as a guideline for policies to promote sustainable mobility. This means that transport policy should attempt to reduce the need to travel and shorten trip lengths, promote a shift to sustainable modes and improve the sustainability of all modes (Brauninger et al., 2012).

\section{The Impact of Income on Mobility}

Unfortunately, the solution to the problem of 'access' is often dealt with through more infrastructure for private needs. For many urban dwellers, the cost of mobility is very high in relation to their household incomes. In cities of developing countries, between 8 and 16 per cent of household income is spent on transport. Among the poorest households in large cities, this rises to more than 25 per cent (UN-Habitat, 2013).

The choice of mobility mode is therefore related to income levels. For those with low incomes, there are very few affordable choices. As a result, in many developing countries, only a small proportion of trips are undertaken using motorised vehicles. The prevalence of long walking trips indicates poor access and a lack of affordable mobility options. 
East African Journal of Business and Economics, Volume 3, Issue 1, 2021

Article DOI: https://doi.org/10.37284/eajbe.3.1.365

Therefore, it is essential that pedestrians are accounted for in any public transport policy.

Public transport is very expensive to establish. Governments in southern countries today have constrained financial and administrative capability to implement and manage public transport systems. Private forms of it are high-priced as their business nature requires that the investors charge high rates in order to make acceptable profit margins above high operational costs. In order for a mass transport means to be successful, it must operate where there are large numbers of people who are able to afford it.

Figure 1: Old Kampala Taxi Park

\section{PUBLIC TRANSPORT IN KAMPALA}

Paratransit as a form of public transport is a mode of shared passenger transportation for use by the public that has no fixed routes or schedules and is operated by individuals and small companies in a flexible, competitive and fragmented manner that is difficult for the government to regulate and therefore control (APTA, 2011). In Kampala, paratransit is the most readily available form of public transport. The major paratransit terminal is the Kampala Taxi Park (Figure 1).

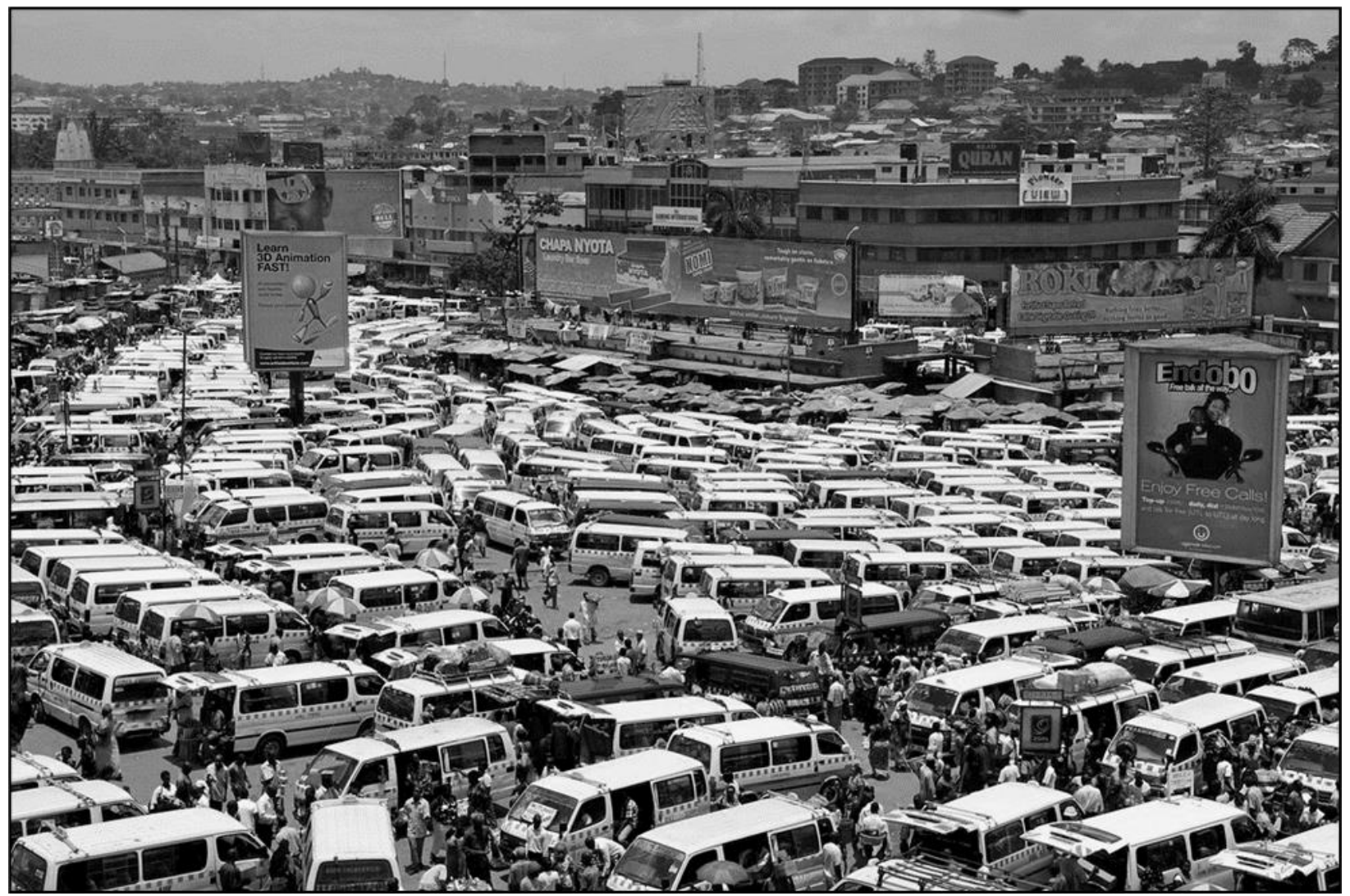

Source: (Eisentrager, 2010)

Public transport in Kampala is largely provided by 'taxis' similar to those shown in Figure 1. Taxis form about $96 \%$ of mass transport in the city (46\% of all transport modes) (KCCA, n.d). Small buses form a small percentage, $4 \%$ of public transport ( $2 \%$ of all transport means in the city). Boda Bodas ferry another $32 \%$ while $19 \%$ use private cars. Taxis, boda bodas and Buses are therefore the only forms of public transport in Kampala City. They handle an average of 7.5 million passengers in the city daily, 
running about 87 routes from the taxi parks into the suburbs. They are privately owned by individuals or mid-sized companies but are supervised by KCCA in their operations. The system has no fixed terminals or routes, scheduled travel times or fixed fares. There are also no adequate public transport laws governing passenger comfort and security (Kitaka, 2019; Government of Uganda, 1995). A draft Taxi Ordinance, yet to be passed by Parliament, has for political reasons been tabled and set aside severally since 2013 (Ngwomoya, 2018). This bill seeks to provide guidelines for the body governing taxis, manage routes and terminals, waste management, fares, the safety of persons and property.

KCCA has made futile attempts to manage and control the paratransit system through tax and penalties. In 2007, the city council pursued the reimplementation of a government-controlled bus system. The objective was to provide a cheaper, cleaner, more comfortable option for commuters that would competitively drive out the need for taxis. The bus service was projected to run throughout the greater Kampala Metropolitan area and have well-defined terminals and bus lanes. The system was launched on March 12 2012, with 100 buses. Though privately owned by vetted companies, the buses had to operate according to strict guidelines. Their routes were defined and their fares were fixed and low (Otage, 2017). Unfortunately, only a few are still operational today. These buses have failed to achieve the objectives for which they were bought. They have difficulty in manoeuvring along roads for which road infrastructure was not designed to support their broad girth. They are slow and rarely available so commuters often cannot rely on them.

\section{The Transport Vision for Kampala 2022}

To overcome the transport problems identified and detailed in the KPDP, the following vision and objectives were proposed under the title, 'The Transportation Vision for Kampala 2022'. Under this vision, by 2022, the Kampala Transport System will be integrated, sustainable and safe, providing access to basic services to all residents in an affordable manner. To meet these objectives, a Transportation Development Strategy was developed with the following sub-sectors: Roads, Public Transport, Non-Motorized Transport and Traffic Management (KCCA, 2014). Sadly, heavy emphasis continues to be placed on strategies to meet subsector 1, the better roadway objective, such as developing new urban freeways, by-passes, ring roads, bridges and new highways taking the burden off the existing routes. This would have little impact on the lives of the urban poor who currently avoid the use of expensive motorised transport. Where they do, it is in the paratransit system, whose needs are not as strongly addressed as the private car. By continuing to serve the interests of a few, the city undermines its sustainable growth objectives.

\section{Non-Motorised Transport (NMT) in Kampala}

Walking and cycling are the most basic urban transport modes for all short-to-medium length travel. They play an essential role in urban transport in most low and middle-income countries worldover. Walking is the most dominant mode of transport in Kampala and accounts for $80 \%$ of the trips performed in the metropolitan area (KCCA, 2012), yet NMT infrastructure lags behind the existing demand levels with almost no direct funding allocated to the improvement and upgrading of pedestrian facilities. More than half of the traffic accident fatalities on Ugandan roads are pedestrians, a statistic unmatched elsewhere in the world. The low quality of the existing NMT facilities deters commuters from walking to their destination and induces the use of other modes (primarily boda-boda or taxi).

Considering the above, therefore, KCCA undertook to target special allocation of non-motorised transport to some sections of the city (KCCA, 2014). Reconstructed or new roadways are adopting new minimum requirements for the accommodation 
of non-motorised transport. Street cross-sections now adopt a walkway and in a few cases, a cycle lane, and the connections between these routes and mass transport terminals are under review in order to maximise integration opportunities. The city is also formulating a comprehensive communication strategy to increase cycling awareness among decision-makers, employers and potential users. By use of pilot programs and reviews, the city hopes to develop non-motorised transport programs that are effective for Kampala. Through policy (such as parking limitations, road reductions and speed limits, et cetera) that prioritise NMT, the city can achieve better traffic management in its centre (KCCA, 2012).

\section{LAND TENURE IN KAMPALA AND ITS IMPACT ON TRANSPORT PLANNING}

Public transport often requires the development of massive infrastructure within a well-structured preestablished framework. Unfortunately, no such accommodation was made in city planning during the colonial era. This large-scale development is made difficult in Kampala by a large number of variations of land tenure and the complicated system governing it. It is quite usual for a road redevelopment project to stall for years as a result of compensation squabbles between the city and landowners along the redevelopment path. At times even one owner alone can cause redirection of the road path! Those affected by redevelopment works have been blackmailed by city officials into inflating compensation proposals impacting both the city in affording implementation and increasing speculation, thereby negatively affecting property pricing (MoFPED, 2019).

In the outline of the threats and obstacles affecting Kampala's Physical Development Plan (KPDP), three key areas were highlighted; slums, wetland encroachment and preservation of transport options. Research has shown that without addressing these three areas, the sustainable future of Kampala is in jeopardy (KCCA, 2014). City governance has analysed and made recommendations concerning the two aspects that concern this research as follows.

\section{Kampala Slums}

A study of the Kampala slums by ACTogether shows that rural-urban migration provides up to $40 \%$ of the residents in the city. The adult-child ratio stands at 2:6; the majority of residents are therefore dependents who are not contributing to household earnings. Reports on slum profiles in the slums of Kalerwe, Kagugube, Kisenyi, Acholi quarters and Bukesa all in Kampala indicated that slums are a sanctuary for the urban poor owing to their proximity to the city, which is a source of employment and access to basic services and amenities such as hospitals, schools, markets. It was found that $50 \%$ of residents lived in these slums all their lives and the majority were tenants. These slums provide cheap and convenient housing even though it may not be of good quality. The ability to save and improve housing, therefore, is very constricted as a large proportion of their income is disposable. Students walk long distances to the few schools available. This however is deemed a small price to pay if work is within easy reach. $80 \%$ of the residents in the Kisenyi settlement are tenants. This means that there is a high level of mobility within the slum. Landlords often stay close by and are few in number compared to tenants. Given better housing opportunities, the residents are in a position to relocate quite quickly if it is their desire. 53.6\% of residents live in fear of eviction by the church, government, city tycoons, and other landlords but reveal that they still prefer to live where they do as their work and amenities are close by (ACTogether, 2011a-e).

\section{METHODOLOGY}

According to Yin (1994), research design links data collected and conclusions drawn to the initial questions of the thesis. Loosely put, the research design is the blueprint or action plan to be followed 
in the research. If a good research design is developed, the data collected will address the initial research questions.

This research was non-experimental and correlational. This means there was no manipulation of the situation, circumstances or experience of the participants. The relationship between a set of quantitative variables was investigated. The strategy employed in this research was two-pronged. It sought to address the research issue from the viewpoint of the individual residing in a slum settlement as well as look at the situation more generally at the city scale. Often issues dealing with settlement are only analysed at city or town scale. New approaches advise that they should also be addressed 'from the bottom up.' This rationale was employed in this research.

The study involved identifying and mapping the location of shanty settlements in Kampala city through the use of archival records from Kampala Capital City Authority (KCCA) and field observation. Data were collected on the location of shanty settlements in Kampala city, means of public transport people from these settlements use to and from work through Kampala City Square, which was used as a central reference point which is centrally located in the CBD along the city's main street and a major transportation terminal. Due to time and money constraints, and to allow the researcher's flexibility and adaptability, the identification of respondents was made through non-probability sampling. The cost and availability of the various modes of public transport from City Square to the select settlements were investigated and mapped using participant observation. Through a survey of residents who shuttle to and from work using the Kampala City Square as the major transportation hub, the study investigated the influence of the public transport system on the decision of these residents to reside in these settlements by analysing its availability, cost and convenience.

\section{RESULTS AND DISCUSSION}

\section{Mapping of Shanty Settlements and Public Transport Routes}

The fieldwork aspect of the study began with a cityscale investigation of the location of shanty settlements and the public transport routes connecting them to the city centre. This helped to update the data on the location of the shanty settlements in the city and to analyse the level of access to the settlements by public transport needs to be assessed to gauge its use by the residents.

Two maps obtained from KCCA were employed as the baseline data. These were adjusted and updated using Google maps. These maps of slum settlements and the road network of Kampala were digitally traced and superimposed to relate the location of the settlements to the transport routes around them. They show that slum settlements in Kampala include Kawempe-Kisowera, Kazo-Angola, Bwaise, Kyebando, Kyebando-Kisalosalo, Kalerwe, Mulago, Katanga, Naguru-Go-Down, Kinawataka, Banda, Kitintale, Luzira, LuziraKirombe, Namuwongo-Soweto, Wabigalo, Kibuli, Kabalagala, Kansanga, Ggaba, Katwe-Kinyolo, Kibuye, Kisenyi, Ndeeba, Kabowa, Nalukolongo, and Nateete-Kigaga. This aggregate map formed the framework on which other information could be placed. Control Points at the borders of the city were selected to provide added reference to distance and cost (Figure 2). 
East African Journal of Business and Economics, Volume 3, Issue 1, 2021 Article DOI: https://doi.org/10.37284/eajbe.3.1.365

Figure 2: Map of Kampala indicating public transport routes and shanty settlements

\section{MAP OF KAMPALA INDICATING PUBLIC TRANSPORT ROUTES AND SHANTY SETTLEMENTS}

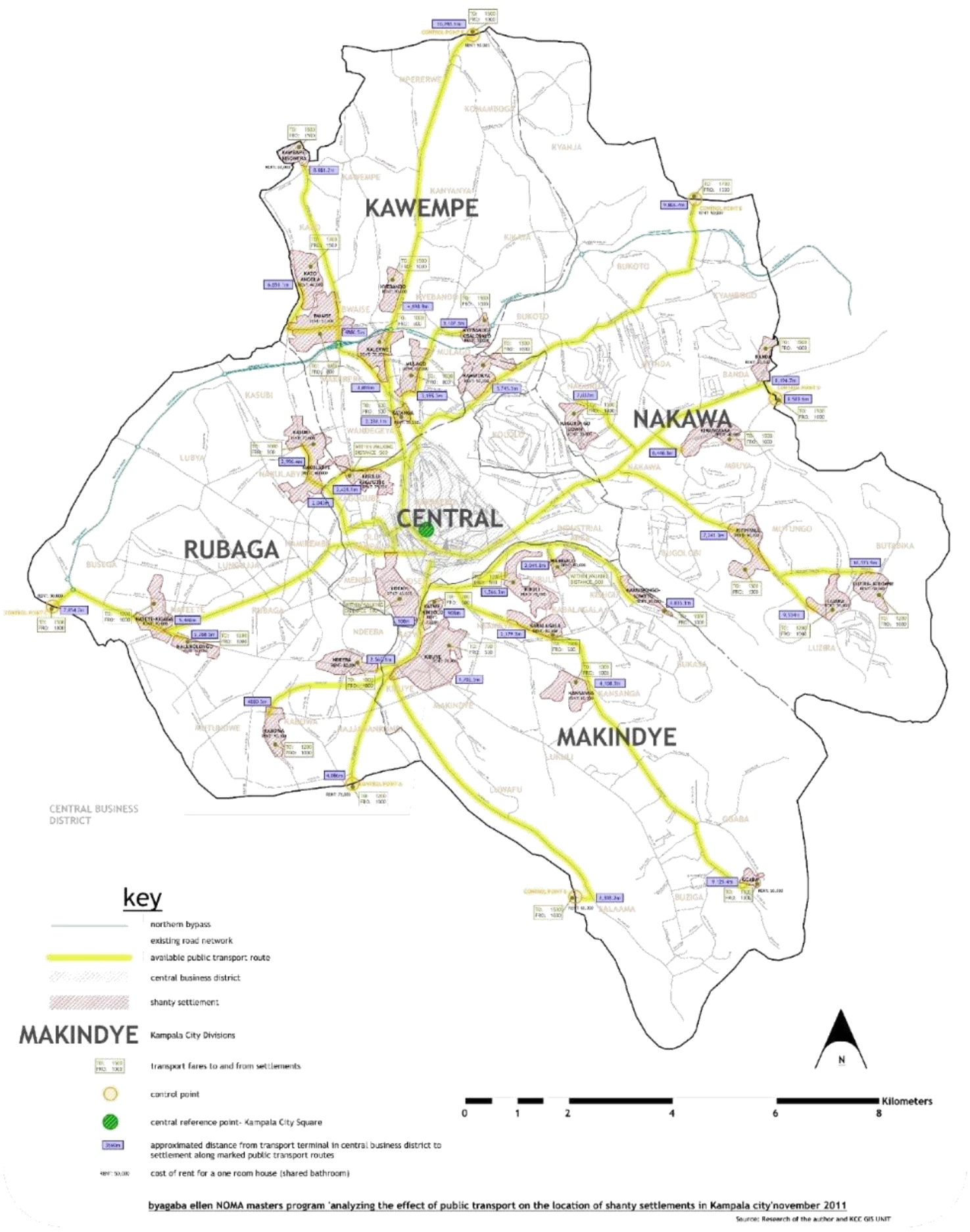

138| This work is licensed under a Creative Commons Attribution 4.0 International License. 
The study revealed that the occurrence of shanty settlements was generally higher close to the Central Business District and in poorly planned areas of the city. The Central division presented the lowest number of shanty settlements because it is also the most well-planned of the five divisions. It is important to note therefore that good planning of the city is the most effective deterrent to the development of illegal settlements. In fact, as discovered during the literature review, it is stated in the Kampala Physical Development Plan (KPDP) that the entire area of Kampala is to be comprehensively planned. This advises that this action already falls within the agenda of city governance and only requires implementation for a good effect to be realised.

\section{Choice of Location of Residence}

Results from respondents showed that the two most important considerations when selecting where to live were the cost of housing and its proximity to where they worked. This illustrates that their objective is for transport costs to have the lowest impact possible on income once the cost of housing is resolved (Figure 3).

\section{Figure 3: Reasons for choice of home location}

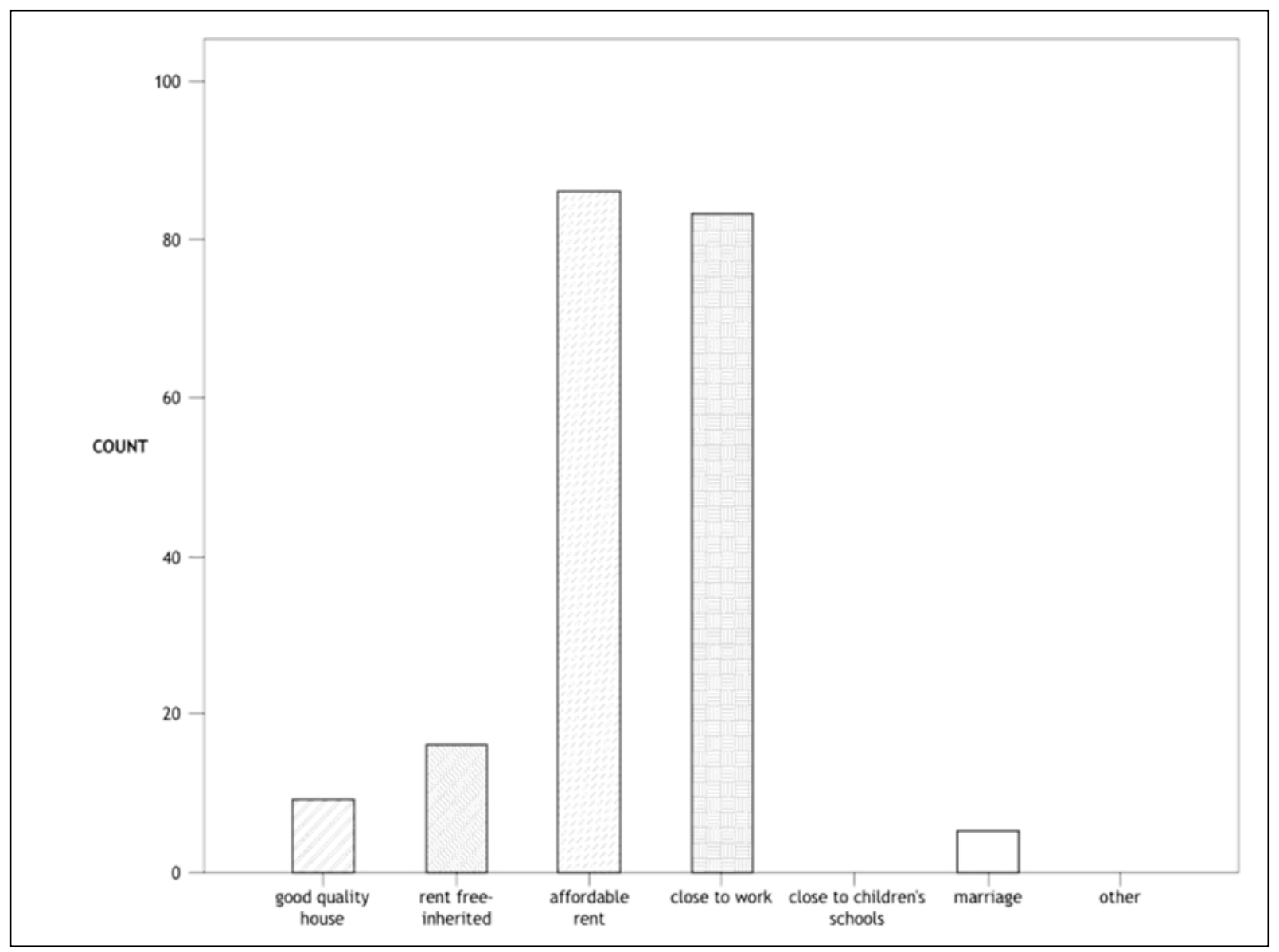

The Nature and Cost of Public Transportation in Kampala

Public transport was found to be widely available and accessible for all the select shanty settlements studied. This was mainly in the form of a 14-sitter commuter taxi and Boda Bodas. However, these means of transport are unreliable and disorganised. No formal schedules, routes, stages or defined fares

139| This work is licensed under a Creative Commons Attribution 4.0 International License. 
exist in this system. This presents a highly variable, unpredictable and therefore largely unaffordable system of movement for the majority of the city population. Constantly changing prices cannot be relied upon while one is planning their expenditure for any significant length of time. In order to understand costs and routes, one must travel whilst seeking guidance as they go, a very uncertain way to travel if one's resources are limited. Taxis ply the most profitable routes, seeking to maximise profits while operating under the loose control of their corporate governing body, UTODA and the city authority. All in all, the transport system is highly uncontrolled. While it is acknowledged that private enterprise must be supported, and the government has limited access to revenue for direct impact on the existing public transportation system. It is important that governance defines greater control on the operation of this system in order to further liberate its users and afford them increased opportunity to plan effective use of it.

\section{The Fare and Reliability}

The average taxi fare or bus fare (whichever was cheaper) charged as one travelled to the various settlements and control points from the central reference point was recorded. The fare was prone to change with a maximum variance of UGX 500 (USD 0.14) during the period of field survey, dependent on factors such as availability (poor weather, particularly rain, traffic jam during peak times, city unrest or insecurity due to demonstrations or strikes by operators. Cautious passengers often ask for clarification on the cost of transportation to their destination before they board the vehicle. The taxis, therefore, do not form a reliable means of movement as one can easily find themselves being forced to pay twice the normal fare or face a very long hike back home. Generally, the city has many taxis that are poorly regulated and operators often compete for space, compounding the congestion in the city and making it less profitable for their business.

\section{The Route}

The route to each settlement, pursued by the public transport means was also recorded on the map. The shortest route was always the cheapest route. Taxis and buses in Kampala City do not ply all the roads; they focus on high traffic corridors. For example, Kazo Angola in Kawempe Division is geographically closer to the central reference point than Kawempe Kisowera. However, because accessing Kazo means you have to disembark from one taxi and use another, results in the fare to Kazo being higher than that to Kisowera which is $1.4 \mathrm{~km}$ further from the reference point than Kazo. Some neighbourhoods such as Kinawataka that are deemed insecure or having poor quality roads also have higher transport costs because they have fewer taxis available to access them.

\section{The Distance}

Along the marked routes to the settlement (using the scaled map from KCCA), measurements were conducted digitally to ascertain the distance of the different settlements and control points from the central reference point. Because measurements were taken along the recognised transport route for which fares had been obtained, the distances were in most cases much longer than the geographical distance to the central reference point.

\section{The Rent}

The final factor of analysis on the map provided a means to compare low-income housing cost around the city. The rent cost for a one-room un-serviced apartment (known locally as a 'muzigo') was recorded on the map. To ensure authenticity, the researchers collected this information by posing as prospective residents and asking landlords how much they would have to pay to occupy such an apartment. 
Income of Respondents and the Cost of jobs was recorded. These include; street vendors,

\section{Commuting by Public Transport in Kampala}

The majority of respondents worked within the shopping malls and taxi stages, in the fresh food stalls, uptown commercial buildings and offices, restaurants, building sites, schools, saloons, fuel stations and factories at or around the central reference point. A wide range of mainly blue-collar casual labourers, Boda Boda cyclists, cooks, hairdressers, cleaners, phone vendors, pump attendants, security guards, waiters, cobblers, taxi louts and shop keepers, among others. Monthly income earnings were computed from an aggregate average of 25 working days in the calendar month and an average daily earning provided by the respondent.

Figure 4: Monthly earnings of respondents

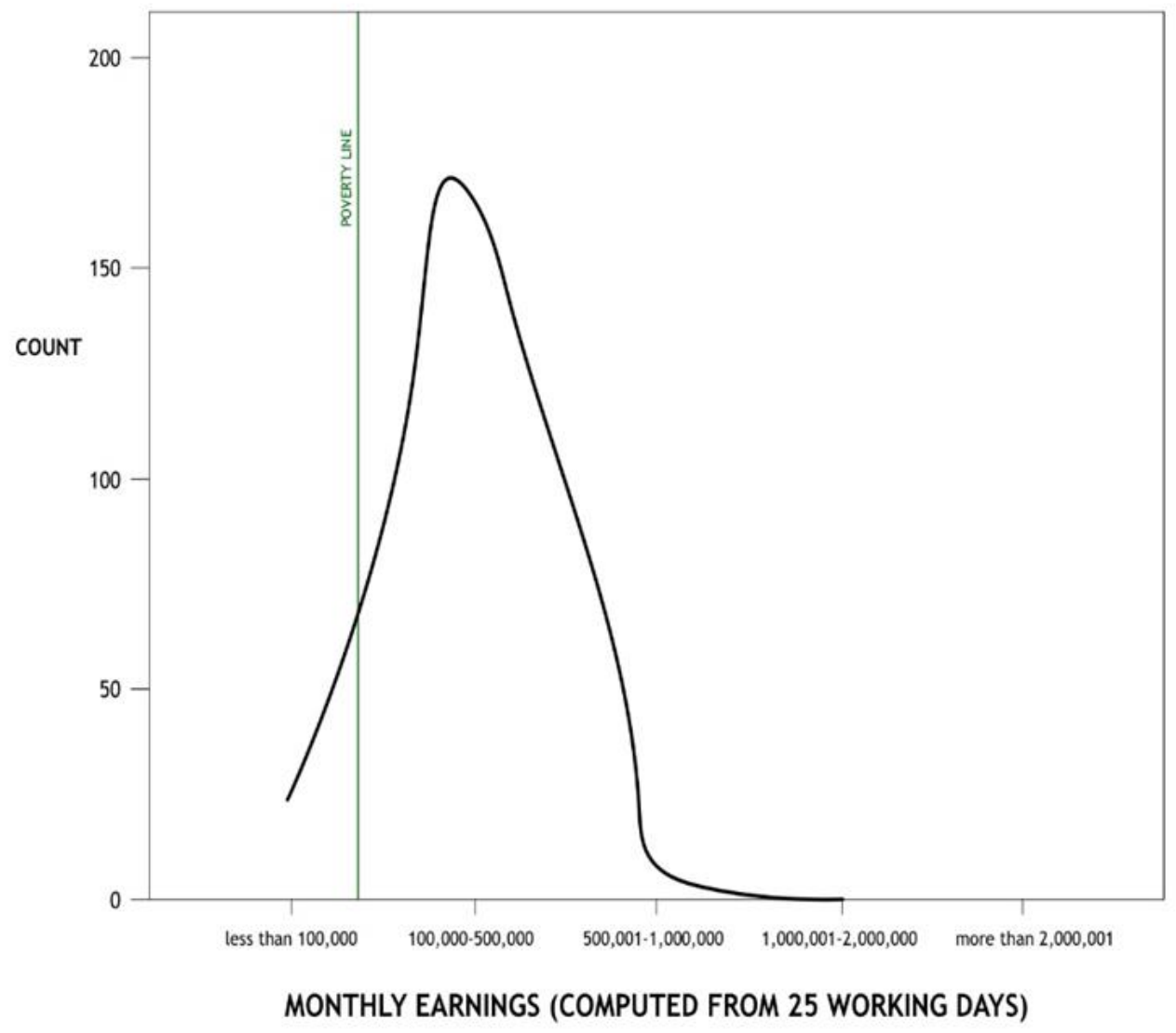

The majority of residents earn between UGShs. $50,000 /=($ USD 13.7) and $100,000 /=($ USD 27.4), while spending between UGShs. 10,000/= (USD 2.74) and UGShs. 100,000/= (USD 27.4) on transport per month (Figure 4). The income bracket defined by the above data describes a very low affordability index for the majority of residents.
This implies combined expenditure on housing and public transport available to them cannot be easily met based on this income. This is further supported by the assertion of respondents that their expenditure on public transport is kept to a bare minimum.

141| This work is licensed under a Creative Commons Attribution 4.0 International License. 
However, the high cost of travel, in general, discouraged the use of public transport for anything other than the very necessary. Most residents were spending a large portion of their income on transport (in some cases up to 50\%). About $64.5 \%$ of the respondents earning between UGShs. 100,000/= and UGShs. 500,000/= (USD 27.4 and USD 137) per month were the ones using taxis most with a monthly travel cost ranging between UGShs. 10,000/ and UGShs. 100,000/= (USD 2.74 and USD 27.4) (Table 1). This indicates that transport is high on the residents' priority list. One of the key necessities for a successful mass transport system is high demand. It is clear that this exists. Unfortunately, any marginal increase in transport costs is crippling for low-income earners; the populace is at the mercy of the private taxi owners and operators. The government can through favourable policy increase the presence of public transport in the city, which would affect the fares across the board, making it more affordable.

Respondents described public transport as 'rarely' used for any reason other than to access the workplace and yet it took a sizeable portion of their income. Living within the city centre places residents in close proximity with amenities such as schools, hospitals and markets. Even though one has to use public transport to work, by negating the cost of any other reason to use transport, costs are kept low. Transport to town in search of amenities would be accessible to all if the fares were lower.

Table 1: Descriptive statistics showing the relationship between income and amount spent on transport

\begin{tabular}{llllll}
\hline Variable & \multicolumn{2}{l}{ Monthly Income } & & \\
Monthly travel costs & $\langle$ than 100,000 & $\mathbf{1 0 0 , 0 0 0} \mathbf{- 5 0 0 , 0 0 0}$ & $\mathbf{5 0 0 , 0 0 1} \mathbf{- 1 , 0 0 0 , 0 0 0}$ & Total & \% \\
\hline Missing & 0 & 2 & 0 & 2 & 1.0 \\
nothing & 9 & 30 & 0 & 39 & 19.5 \\
$50-500$ & 0 & 2 & 0 & 2 & 0.5 \\
$501-10,000$ & 12 & 44 & 0 & 56 & 14.0 \\
$10,001-100,000$ & 16 & 230 & 12 & 258 & 64.5 \\
More than 100,000 & 0 & 2 & 0 & 2 & 0.5 \\
Total respondents & 46 & 342 & 12 & 400 & 100.0 \\
\% of total respondents & 11.5 & 85.5 & 3.0 & 0 & 100.0 \\
\hline
\end{tabular}

$19.5 \%$ of respondents claimed to spend none of their monthly income on transport. This is a significant number when you consider that such a proportion of the population chooses not to use any form of public transport by keeping all their needs close.

Conversely, the more people earned, the less satisfied they were with public transport, for safety, comfort, convenience and security reasons. To ensure the demand of middle to high-income earners for public transport, it must be safe, convenient and comfortable. The lowest income earners expressed a lower level of satisfaction than the low to middle-income bracket because of dissatisfaction with cost and service value for money. In order to ensure their demand, the fares must be cheaper. If the needs of the different strata of the population are being met, public transport will be successful in meeting the needs of Kampala.

The cost of available transportation options is expensive for the urban low-income earner, the primary resident of shanty settlements. It is important to note that majority of the residents of shanty settlements cannot afford to use public transport to access their places of work on a regular basis. Therefore, that any manipulation targeting lowering of costs in turns widens the scope of city residents to be serviced by the system. Affordability prescribes increased opportunities for mobility. 
Increased mobility in turn would result in increased housing choice for city residents.

\section{The Cost of Housing in Different Locations}

The citywide study indicated that generally, the same quality and type of housing was cheaper at the outskirts of the city than at the centre. Variances were noted where settlements were located close to areas with many job opportunities such as Mulago. The same trend was seen in the ACTogether reports obtained from local NGOs. It can therefore be concluded that if transport were affordable, a lowincome earner would be more affordable and therefore preferably situated in better quality housing at the outskirts than in illegal housing at the centre of the city.

Land tenure has a significant impact on both costs of housing and the expansion of the transportation system. Land just outside city bounds is much cheaper than that within because of expensive legal processes operated by KCCA and speculation by landowners. The data indicated on the map compares illegal housing at the centre and at the outskirts. A comparison between two similar houses, situated at the centre of the city and outside the city would indicate the same result; it is cheaper to live outside Kampala district bounds. Expanding roadways to include bus lanes and pedestrian walkways is also made difficult by the land tenure system in Kampala. The allocation of land in Kampala and, therefore, subdivision and sale processes need to be revised to ensure the healthy growth of the city.

Use of public transport for other reasons must be encouraged. This can be achieved if it is made affordable. When selecting a particular location for a home, the most important reasons were described as primarily; if it was affordable and secondly if work was located close by. By making public transport affordable, the cost of housing becomes the only major consideration. Ideally, this would mean people would select the most affordable housing they can get at their income level. For the lowest income earners, this would not be at the city centre.

Results indicated that those who lived far away spent significantly more on transportation. They also expressed less satisfaction with the public transport system in general. Those who lived near were statistically happier. The fact that though the location of employment changed, respondents did not relocate attests to the actuality that it is more preferable to travel a short distance to work and maintain a walkable distance to amenities. The lack of correlation between satisfaction with the public transport system and the number of times people moved indicates that the choice on where to live was never tied to a need to access affordable transport other than for work (amenities must always remain close). This could mean that they did not encounter a significant change in the amount spent on transport. This is possible if public transport is used only to access work and if, although high, the fares are fairly even throughout the city.

\section{The Affordability Index of the Shanty Settlement Resident}

Lipman (2006) in his research discovered that the lowest affordability index in cities presented in urban locations. This research has established that this is also true in Kampala. Affordability was achieved at its minimum when the cost of transport was reduced to zero. Since the earnings of the target population are low, it stands that their affordability index is also low. Respondents also presented an increase in the use of public transport as income increased. This indicates that where affordable, public transport would be readily accessed. It, therefore, implies that any action lowering the cost of transportation significantly improves the livelihood of city dwellers by increasing their accessibility to transportation whilst allowing a greater portion of income to become available for better quality housing or other necessary amenities. It also allows one the opportunity to reside further 
away from the place of work whilst maintaining the same affordability index.

While resource limitations and a propensity to reflexivity and bias by respondents limited the research, a strong correlation between the cost of public transportation and the choice to locate in shanty settlements in Kampala was documented. Residents of Kampala's shanty settlements largely cannot afford to use public transport to access their work every day, or at the very least for the full length of the journey. They are opting to live as close to their places of work as possible to negate this cost.

Although the scope of the study restricted itself to the discussion of cost as a factor of access to public transport and did not investigate other prevailing factors affecting public transport use or shanty settlement development, it still presented strongly for the existence of a relationship for manipulation to achieve improvement for both variables. At the very least, this is an area of research for further exploitation as it presents a significant opportunity for sustainable change.

\section{CONCLUSIONS}

From the above discussion, the study showed that by encouraging the development of mass transport, through government-led enforcement of revised policy and laws that encourage public transport and discourage private motorisation, the cost of transportation to one's place of work could be reduced. Findings revealed that lower fares increase the mobility of the residents in shanty settlements in Kampala and open up greater choice as to where they can reside. Residents are therefore able to comfortably afford better quality housing at the outskirts of the city; a choice likely to be made over living in illegal, unsanitary inner-city slums if their affordability index (the aggregate of expenditure on housing and transport) remains the same or reduces.

This study clearly illustrates a strong correlation between the cost of public transport and the choice of residents to live in shanty settlements to negate that cost to its bare minimum in accessing the most critical, their employment. Where many opportunities for improvement of the paratransit system have been observed, perhaps the most profound lie with city governance. Policy and law reform can significantly lower the cost of transport and in turn, improve the mobility of city dwellers. Improvement of transport infrastructure, for example, adhering to road reserve requirements and allowances for non-motorised means as well tax subsidies on the importation of transport vehicles and their commissioning could improve transport availability and hence reduce its costs.

\section{REFERENCES}

ACTogether. (2011a). Kisenyi III Enumeration Data. Uganda Slum Dwellers Federation

ACTogether. (2011b). Slum Profile Report: Kalerwe. Uganda Slum Dwellers Federation

ACTogether. (2011c). Slum Profile Report: Kagugube. Uganda Slum Dwellers Federation

ACTogether. (2011d). Slum Profile Report: Acholi Quarters. Uganda Slum Dwellers Federation

ACTogether. (2011e). Slum Profile Report: Bukesa. Uganda Slum Dwellers Federation

APTA (2011). Glossary of Transit Terminology. American Public Transportation Association.

Boarnet, M. G., Greenwald, M., \& McMillan, T. E. (2008). Walking, urban design, and health: toward a cost-benefit analysis framework. Journal of Planning Education and Research, 27(3), 341-358.

Bräuninger, M., Schulze, S., Leschus, L., Perschon, J., Hertel, C., Field, S., \& Foletta, N. (2012). Achieving sustainability in urban transport in developing and transition countries. DessauRoßlau, Germany: Federal Environment Agency (Germany)

144| This work is licensed under a Creative Commons Attribution 4.0 International License. 
Duc, L. (2007). The Interdependence of Transport and Housing Development in the Transition of Hochiminh City. CODATU.

Eisentrager, S. (2010, September 08). Kampala New Taxi Park. Flickr. https://www.flickr.com/phot os/eisentrager/4991730808

Greed, C. and Roberts, M. (1998). Introducing Urban Design: Interventions and Responses. Addison Wesley Longman Ltd.

Hagans, C. (2013). Livelihoods, land-use \& public transport: Opportunities for poverty reduction and risks of splintering urbanism in Nairobi's Spatial Plans. DPU WORKING PAPER 159

Holcombe, R. (1999). In Defence of Urban Sprawl. Montana, USA: Political Economy Research Centre

KCCA. (2012). Kampala Physical Development Plan. Kampala Capital City Authority.

KCCA. (2014). Strategic Plan 2014/15-2018/19 Laying the foundation for Kampala City Transformation. Kampala Capital City Authority.

KCCA. (n.d.). The Authority. Retrieved October 2019 from Kampala Capital City Authority, https://www.kcca.go.ug/about-theauthority\#: :text=Kampalapercent20ispercent2 Odividedpercent20intopercent20five, underperce nt20thepercent20newpercent20KCCApercent20 Law.

Kelly, E. D. (1994). The transportation land-use link. Journal of Planning Literature, 9(2), 128145 .

Lipman, B. (2006). A Heavy Load: The Combined Housing and Transport Burdens of Working Families. Centre for Housing Policy.

Litman, T. (2011). Where We Want To Be: Home Location Preferences and their Implications for
Smart Growth. Victoria Transport Policy Institute.

Litman, T. (2014). Evaluating Transportation Equity - Guidance for Incorporating Distributional Impacts in Transportation Planning. World Transport Policy \& Practice

Mabogunje, A. (2006). Foundations for Urban Development in Africa. The Cities Alliance.

Ministry of Finance, Planning and Economic Development (MoFPED) (2019). Budget Monitoring and Accountability Unit: Briefing Paper 27/19. Government of Uganda.

Ngwomoya, A. (2018, May 18). KCCA makes law to regulate city taxis. The Daily Monitor. Retrieved from https://www.monitor.co.ug/uganda/news/nation al/kcca-makes-law-to-regulate-city-taxis1756790

Otage, S. (2017, November 17). Was Pioneer bus case study for Kampala City transport? The Daily Monitor. Retrieved from https://www.monitor.co.ug/uganda/news/nation al/was-pioneer-bus-case-study-for-kampalacity-transport--1726448

OTREC. (2009). Co-Evolution of Transportation and Land Use: Modelling Historical Dependencies in Land Use and Transport Decision Making. Oregon Transportation Research and Education Consortium

Pojani, D., \& Stead, D. (2015). Sustainable urban transport in the developing world: beyond megacities. Sustainability, 7(6), 7784-7805.

Starkey, P., \& Hine, J. (2014). Poverty and sustainable transport: how transport affects poor people with policy implications for poverty reduction. A literature review. Nairobi, KE: UNHabitat, and the Overseas Development Institute (ODI).

145 This work is licensed under a Creative Commons Attribution 4.0 International License. 
Suzuki, H., Cervero, R., \& Iuchi, K. (2013). Transforming cities with transit: Transit and land-use integration for sustainable urban development. World Bank Publications.

UNCHS. (2001). The role of urban transport in sustainable human settlements. Background paper No. 7. Nairobi, KE: United Nations Centre for Human Settlements.

UN-Habitat. (2013). Global Report on Human Settlements: Planning and Design for Sustainable Urban Mobility. Nairobi, KE: UNHabitat.

United Nations (2021, June 9). Goal 11: Make cities and human settlements inclusive, safe, resilient and sustainable. https://unstats.un.org/ sdgs/report/2017/goal-11/.

Vinay, L. S.; Henderson. J. V.; and Venables, A. J. (2017). Africa's Cities: Opening Doors to the World. Washington, DC: World Bank.

Yin, R. (1994). Case Study Research: Design and Methods. Sage Publications 